\title{
RISK FACTORS ASSOCIATED WITH BLACK TOOTH STAIN
}

\author{
Katica Prskalo ${ }^{1}$, Eva Klarić Sever ${ }^{1}$, Ivan Alerić 2 , Tatjana Antonić Jelić ${ }^{3}$ and Ivona Žaja ${ }^{4}$
}

${ }^{1}$ Department of Endodontics and Restorative Dentistry, School of Dental Medicine, University of Zagreb, Zagreb; ${ }^{2}$ School of Medicine, Josip Juraj Strossmayer University, Osijek; ${ }^{2}$ Zagreb University Hospital Centre; ${ }^{3}$ Ruđer Bošković Institute; ${ }^{4}$ Žaja Private Dental Practice, Zagreb, Croatia

\begin{abstract}
SUMMARY - The aim of the study was to show whether there is any influence of food, drink or drug intake on the formation of tooth discoloration. A total of 500 patients aged 15-25 years were examined to take part in the study. Of these, 60 patients were selected and divided into two groups of 30 patients each. Group 1 included patients with black pigmentation on vestibular/oral tooth surfaces. Group 2 included patients without discoloration (control). Data were recorded in a questionnaire. Atomic absorption spectrometry was used to determine elements in discoloration samples. The Caries Risk Test (CRT) buffer was used to assess buffer capacity of saliva, while CRT bacteria were used to determine the presence of Streptococcus mutans and Lactobacillus spp. Statistically significant betweengroup differences were found for the intake of collard greens and beets $(p<0.05)$, but not for other vegetables. As for drink consumption, patients with pigmentation reported less wine intake $(\mathrm{p}<0.05)$ than those without pigmentation. There was no difference according to drug intake between patients with and without pigmentation. Patients with pigmentation were older, smoked and had lower saliva $\mathrm{pH}$ with lower presence of Streptococcus mutans than those without pigmentation $(\mathrm{p}<0.05)$. In tooth discoloration samples, there were traces of calcium, magnesium, iron, copper and zinc. The appearance of tooth discoloration is influenced by many factors, among which diet and saliva seem to be very important. Our study showed that patients with black pigmentation used to take more beets, while patients without pigmentation were taking more collard greens and red wine.
\end{abstract}

Key words: Teeth; Black pigmentation; Diet; Saliva

\section{Introduction}

Tooth discoloration is a common clinical finding, which is considered primarily as an aesthetic problem. It can be influenced by many different factors and usually differs in etiology, appearance, composition, location and degree of adherence ${ }^{1}$. There are two types of tooth discolorations, i.e. those related to intrinsic factors such as congenital or systemic influence and inherited conditions, and those caused by extrinsic factors. Tooth development defects, pulp disease and im-

Correspondence to: Eva Klaric Sever, DDM, Department of Endodontics and Restorative Dentistry, School of Dental Medicine, Gundulićeva 5, HR-10000 Zagreb, Croatia

E-mail: eklaric@sfzg.hr

Received February 12, 2016, accepted March 21, 2016 proper endodontic treatment can also cause internal or endogenous tooth discolorations. Contrary to the internal tooth discoloration, external tooth discoloration is due to the formation of pigmentations on the enamel surface ${ }^{2}$.

The first step in tooth discoloration is the formation of pellicle. A few hours after its formation, bacterial colonization leads to plaque formation. Dentobacterial plaque is a soft layer of microorganisms in matrix rich in polysaccharides and glycoproteins, which are firmly attached to the tooth surface ${ }^{2}$. Plaque composition is influenced by internal (genetic tooth formation, composition and amount of saliva), as well as external factors (composition and food consistency and hygiene habits).

In the oral cavity, the appearance of tooth discolorations is related to their etiology, composition, amount, 


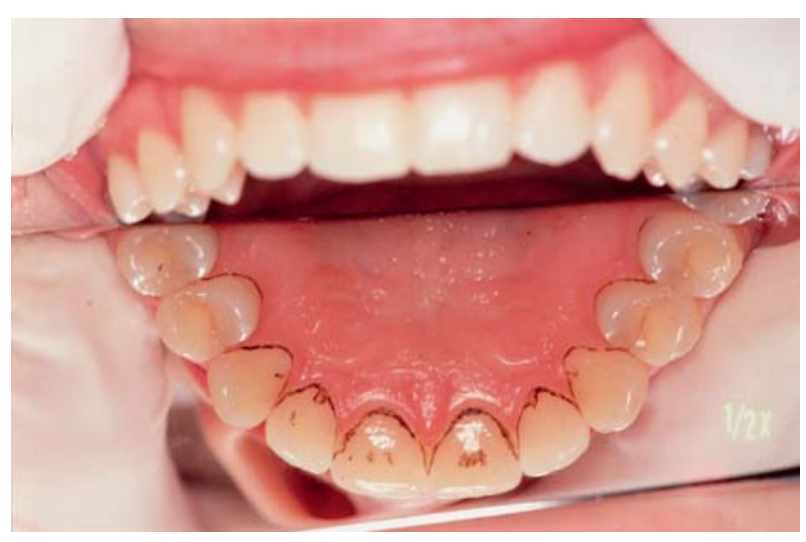

Fig. 1. Pigmented tooth discolorations in the upper jaw.

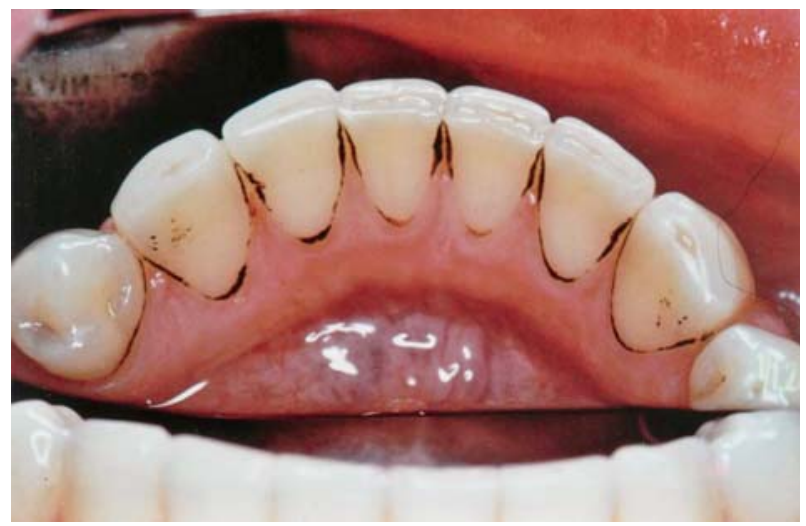

Fig. 2. Pigmented tooth discolorations in the lower jaw.

hardness and attachment to the tooth enamel ${ }^{3}$. Yellow, green and orange discolorations caused by chromogenic bacteria from dentobacterial plaque are soft and usually found in patients with low oral hygiene and in children ${ }^{1,4}$. Brown or black discoloration is mostly localized closely to gingival margin (Figs. 1 and 2). They are firmly attached to the tooth surface and are common in children and adults with good oral hygiene and low caries incidence ${ }^{5,6}$. Black extrinsic stains are usually biofilms formed on the vestibular and oral surfaces of teeth and are characterized by dark spots made of insoluble iron salt and high concentrations of calcium and phosphate ions ${ }^{7}$. Ferric sulfide can be formed by the reaction between hydrogen sulfide produced by bacterial action and iron in the saliva or gingival sulcus fluid. In one study, a group of 6-year-old Spanish children with black stain had consumed a significantly higher proportion of iron supplements than children without black stains ${ }^{8}$. Chromogenic bacteria are also an etiologic factor in the production of black pigment.
Usual periodontal pathogens such as Porphyromonas gingivalis, Prevotella intermedia and Prevotella nigrescens are reported to be black-pigmented anaerobes in oral cavity. They are dependent on the heme portion of hemoglobin due to iron importance for bacterial growth ${ }^{9}$.

According to Harald et al. ${ }^{1}$, tooth pigmentation is formed by precipitation of chromogenic bacteria from dentobacterial plaque, deposition of colored substances from the substrate present in the oral cavity, or formation of colored substances due to chemical decomposition of pellicle components. Nathoo classification $^{10}$ is based on chemical mechanism of the formation of discoloration. N1 type refers to colored material (chromogen), which has been bonded on the tooth surface and leads to tooth discoloration. Food and drink (tea, coffee, wine) can lead to the formation of discoloration by direct precipitation of chromogen on the tooth surface. In this case, the color of discoloration is the same as the color of the chromogen. The same holds for patients working in copper (green pigmentation) and iron (black pigmentation) industry, as well as in patients with iron treatment ${ }^{11-13}$. N2 type refers to chromogenic material that changes color after bonding to the tooth surface. This leads to yellowish pigmentation on proximal and gingival tooth surfaces and more rapid formation of brown pigmentation with aging. N3 refers to non-colored material or pre-chromogen that is bonded to the tooth surface and is chemically changed causing tooth discoloration. The most common is Millard or non-enzymatic brown reaction. An example of this reaction is darkening of food rich in carbohydrate and sugar such as apples and potatoes $^{12-14}$.

The purpose of the present study was to evaluate if there is any influence of food and drink intake (eating habits), drug consumption, smoking, presence of bacteria and saliva $\mathrm{pH}$ on the formation of black tooth discoloration and to determine the metal composition of such pigmentation.

\section{Materials and Methods}

The study was approved by the Ethics Committee of the School of Dental Medicine, University of Zagreb. Clinical examination was performed in 500 patients aged 15-25 years, at the Department of Endodontics and Restorative Dentistry and Department 
of Orthodontics, School of Dental Medicine, University in Zagreb and Zagreb Dental Clinic. Of the total number of examined patients, 60 patients were selected and divided into two groups of 30 patients each. Group 1 included patients with black pigmentation on vestibular/oral tooth surfaces. Group 2 (control) included patients without discoloration on clinical examination. The criteria for inclusion in control group were good oral hygiene, fewer tooth fillings and extracted teeth, and no prosthodontic replacement. Data were recorded in a questionnaire.

The Caries Risk Test (CRT) buffer (Ivoclar Vivadent, Liechtenstein) was used to determine buffer capacity of saliva by use of a test strip featuring a special indicator system. Salivation was stimulated by chewing a paraffin pellet for 5 minutes and then the test field was soaked with saliva using a pipette. Blue color indicated high and yellow color low buffer capacity of saliva.

The CRT Bacteria test (Ivoclar Vivadent, Liechtenstein) was used to determine the presence of Streptococcus(S.) mutans and Lactobacillus spp. in saliva by use of selective culture media. Protective foils were removed from the two agar surfaces and both agar surfaces were wetted with saliva using a pipette. $\mathrm{NaHCO} 3-$ tablet was placed at the bottom of the vial without touching the agar. The agar was then placed in a thermostat (Cultura Ivoclar Vivadent, Liechtenstein) at 37 ${ }^{\circ} \mathrm{C}$ for 48 hours. After removal of the vial from the incubator, density of the S. mutans and Lactobacillus spp. colonies was compared with the respective evaluation picture in the model chart enclosed. Atomic absorption spectrometry (AAS) (Perkin Elmer 3030B, USA) was used for quantitative determination of elements in tooth discoloration samples. It analyzes metals in biological fluids by using wavelengths of light specifically absorbed by an element. Samples from five randomly selected discolorations were taken using sterile metal curettes and stored in plastic containers with $1 \mathrm{~mL}$ of deionized water. Each sample was weighed by precise scale (E. Metter, Switzerland) and made up to a solution using chlorine acid $(\mathrm{HCl})$ and deionized water to make a suitable dilution. The samples were diluted to the minimal volume possible for metal concentration measurements (ppm, $\mathrm{mg} / \mathrm{mL}$ ). In this study, the levels of trace elements calcium $(\mathrm{Ca})$, magnesium $(\mathrm{Mg})$, iron $(\mathrm{Fe})$, copper $(\mathrm{Cu})$ and zinc $(\mathrm{Zn})$ were determined.

The data collected were statistically analyzed using robust discriminant analysis and univariate analysis of variance. Statistical analysis was performed in SPSS 20 (IBM, Armonk, NY, USA) with $\alpha=0.05$.

\section{Results}

The incidence of pigmented discoloration in study patients was $6 \%$, as calculated using the formula: (number of patients with tooth discolorations/total number of examined patients) $x 100$. The frequency of vegetable consumption is shown in Table 1 . Statistically significant between-group differences were found for the intake of collard greens $(\mathrm{p}=0.011)$ and beets $(p=0.033)$, whereas there were no such difference for other vegetables. The mean values reveal that patients with pigmentation used to take more beets as compared to patients without pigmentation. In case of collard greens, the results were opposite. Patients with pigmentation had centroid -0.66 , whereas patients without pigmentation had centroid 0.66 of standard deviations. The results of univariate analysis of variance showed the highest significant level for red wine intake. Patients with pigmentation used to take less red wine $(\mathrm{p}=0.001)$ than those without pigmentation (Table 2).

Table 1. Univariate analysis of variance for various green vegetables

\begin{tabular}{|c|c|c|c|c|c|c|}
\hline \multirow[b]{2}{*}{ Variable } & \multicolumn{2}{|c|}{ Mean value } & \multirow{2}{*}{$\begin{array}{l}\text { Standard } \\
\text { deviation }\end{array}$} & \multirow[b]{2}{*}{$\mathrm{F}$} & \multirow[b]{2}{*}{$\begin{array}{l}\mathrm{DF} 1=1 \\
\mathrm{DF} 2=58\end{array}$} & \multirow{2}{*}{$\begin{array}{l}\text { Level of } \\
\text { significance }\end{array}$} \\
\hline & \begin{tabular}{|l|} 
With \\
discolorations
\end{tabular} & $\begin{array}{l}\text { Without } \\
\text { discolorations }\end{array}$ & & & & \\
\hline Swiss chard & -0.21 & 0.21 & 1.09 .86 & 3.61 & & 0.059 \\
\hline Spinach & -0.06 & 0.06 & 1.07 .92 & 1.22 & & 0.274 \\
\hline Collard greens & -0.30 & 0.30 & 0.871 .03 & 6.90 & & 0.011 \\
\hline Broccoli & -0.15 & 0.15 & 1.07 .90 & 2.37 & & 0.125 \\
\hline Beet & 0.24 & -0.24 & 0.851 .08 & 4.67 & & 0.033 \\
\hline
\end{tabular}


Table 2. Univariate analysis of variance for various drinks

\begin{tabular}{|l|l|l|l|l|l|l|}
\hline \multirow{2}{*}{ Variable } & \multicolumn{2}{|c|}{ Mean value } & Standard \\
\cline { 2 - 6 } & $\begin{array}{l}\text { With } \\
\text { discolorations }\end{array}$ & $\begin{array}{l}\text { Without } \\
\text { discolorations }\end{array}$ & F & $\begin{array}{l}\text { DF1=1 } \\
\text { DF2=58 }\end{array}$ & $\begin{array}{l}\text { Level of } \\
\text { significance }\end{array}$ \\
\hline Coca-Cola & -0.07 & 0.07 & 1.04 .96 & 1.29 & & 0.260 \\
Mineral water & 0.12 & -0.12 & 0.871 .11 & 1.88 & & 0.172 \\
Red juices & 0.20 & -0.20 & 1.000 .96 & 3.41 & & 0.066 \\
Tea & -0.20 & 0.20 & 0.911 .05 & 3.34 & & 0.069 \\
Red wine & -0.57 & 0.57 & 0.630 .98 & 29.31 & & 0.000 \\
Coffee & 0.12 & -0.12 & 0.801 .16 & 1.80 & & 0.182 \\
Others & -0.08 & 0.08 & 1.05 .94 & 1.36 & & 0.247 \\
\hline
\end{tabular}

Table 3. Results of univariate analysis of variance for other factors

\begin{tabular}{|c|c|c|c|c|c|c|}
\hline \multirow[b]{2}{*}{ Variable } & \multicolumn{2}{|c|}{ Mean value } & \multirow{2}{*}{$\begin{array}{l}\text { Standard } \\
\text { deviation }\end{array}$} & \multirow[b]{2}{*}{$\mathrm{F}$} & \multirow{2}{*}{$\begin{array}{l}\mathrm{DF} 1=1 \\
\mathrm{DF} 2=58\end{array}$} & \multirow{2}{*}{$\begin{array}{l}\text { Level of } \\
\text { significance }\end{array}$} \\
\hline & \begin{tabular}{|l|} 
With \\
discolorations
\end{tabular} & \begin{tabular}{|l} 
Without \\
discolorations
\end{tabular} & & & & \\
\hline Iron & 0.07 & -0.07 & 1.22 .71 & 1.26 & & 0.266 \\
\hline Antacids & -0.20 & 0.20 & 0.951 .01 & 3.53 & & 0.062 \\
\hline Vitamins & 0.07 & -0.07 & 0.871 .11 & 1.31 & & 0.256 \\
\hline Age & 17.26 & 22.26 & 3.452 .10 & 57.76 & & 0.000 \\
\hline Smoking & 0.97 & -0.97 & $0.35 /$ & 920.59 & & 0.000 \\
\hline $\mathrm{pH}$ & -0.34 & 0.34 & 0.900 .99 & 8.57 & & 0.005 \\
\hline Streptococcus mutans & -0.41 & 0.41 & 0.950 .87 & 12.65 & & 0.001 \\
\hline Lactobacillus spp. & 0.18 & -0.18 & 0.931 .04 & 3.01 & & 0.084 \\
\hline
\end{tabular}

Table 4. Quantitative determination of elements in tooth discoloration samples

\begin{tabular}{|l|l|l|l|l|l|}
\hline Sample & $\mathrm{Ca}$ & $\mathrm{Mg}$ & $\mathrm{Fe}$ & $\mathrm{Cu}$ & $\mathrm{Zn}$ \\
\hline 1 & $3.701 \times 10^{-2}$ & $3.219 \times 10^{-3}$ & $1.164 \times 10^{-3}$ & $2.514 \times 10^{-4}$ & $3.687 \times 10^{-3}$ \\
2 & $3.348 \times 10^{-1}$ & $1.254 \times 10^{-2}$ & $6.622 \times 10^{-4}$ & $1.646 \times 10^{-4}$ & $7.008 \times 10^{-4}$ \\
3 & $5.364 \times 10^{-3}$ & $4.647 \times 10^{-4}$ & $2.023 \times 10^{-4}$ & $2.604 \times 10^{-4}$ & - \\
4 & $6.353 \times 10^{-2}$ & $1.340 \times 10^{-3}$ & $4.250 \times 10^{-4}$ & $4.389 \times 10^{-5}$ & $4.013 \times 10^{-4}$ \\
5 & $7.507 \times 10^{-2}$ & $1.209 \times 10^{-2}$ & $8.02 \times 10^{-4}$ & $1.576 \times 10^{-4}$ & $5.416 \times 10^{-4}$ \\
\hline
\end{tabular}

The structure of discrimination function, i.e. differences between patients with and without pigmentation in drug intake, age, smoking, saliva $\mathrm{pH}$, and $S$. mutans and Lactobacillus spp. concentrations are shown in Table 3. There was no difference in drug intake (iron, antacids, and vitamins) between patients with and without pigmentation. Patients with pigmentation were on average older $(p=0.000)$, smoked $(p=0.002)$ and had lower saliva $\mathrm{pH}(0.005)$ with lower presence of $S$. mutans ( $\mathrm{p}=0.001)$ than patients without pigmen- tation. Quantitative determination of elements in tooth discoloration samples using AAS are shown in Table 4.

\section{Discussion}

Aesthetics and color of the teeth are reflection of systemic health. Many intrinsic or extrinsic factors can influence tooth color. Tooth color is usually compromised by some discoloration or staining, either on an 
individual tooth or on all teeth. Formation of pigmented tooth discolorations on tooth surface can be a consequence of different local factors. Intrinsic stains are related to enamel and dentin properties, whereas extrinsic stains are associated to deposition of either food or beverage stains on the tooth surface, poor tooth brushing techniques, smoking, dietary intake of tannin-rich foods, excess use of chlorhexidine mouth wash, and/or consumption of metal salts ${ }^{15,16}$. Also, isolated yellow, brown, black or white areas on an enamel surface are common ${ }^{17-19}$. Organic chromogens are taken up by the pellicle and the color imparted is determined by the natural color of the chromogen and the color seen on the tooth is considered to be derived mostly from polyphenolic compounds ${ }^{15,16}$. Most of the former stimulated experiments trying to find correlation between the consumption of red wine, tea and coffee, and the formation of tooth discolorations. However, all these substances have in their composition tannic acid, which denatures saliva proteins and leads to the formation of brown discolorations ${ }^{20}$. Tannin contains polyphenols such as catechins and leucoanthocianins, which have strong denaturing effects on pellicle proteins ${ }^{1,21,22}$. It is interesting to observe the composition of pigments and fibers in beets and red wine, which has major influence on pigment formation on the tooth surface in comparison with collard greens. Beets have pigments betacyanins (mostly betaine) and betaxanthine; grapes anthocyanins; and collard greens have chlorophyll, lutein and beta-carotene. Considering fiber percentage in the mentioned foods, grapes have the lowest percentage of fibers (4\%), followed by beets $(7 \%)$, while collard greens have the highest fiber percentage $(5 \%-12 \%)^{10}$. Due to fiber percentage, this can be connected with the frequency of pigment formation because fibers enable mechanical cleaning and less pigment precipitation. However, study results indicate that grape has fewer fibers than beets, which can lead to a conclusion that beets will cause less pigment deposition than red wine ${ }^{10}$. Our study included vegetables and drinks that possess most of the pigments, which can lead to tooth discoloration of the enamel surface. The incidence of pigmented discoloration in our patients was 6\%. Highly pigmented vegetables such as Swiss chard, spinach, collard greens, broccoli and beet were considered in this study. Statistically significant difference was found for beets and green collard intake. More discolorations were found in patients with more beet intake, while opposite results were found for green collard intake, which can be associated with lower fiber percentage in beets as compared with collard greens. Also, red wine, coffee, tea, Coca-Cola, red juices and mineral water were examined as potential discoloration factors. Statistically significant difference was only found for red wine intake. Patients with tooth discolorations consumed less red wine than patients without discolorations, which is contrary to the previously mentioned studies reporting that highly pigmented beverages such as black tea and red wine cause extrinsic tooth discoloration ${ }^{23-25}$. Our findings might be explained by the fact that wine stays in the oral cavity shorter than vegetables and therefore there is less opportunity for pigment formation ${ }^{10}$. It is interesting to notice that Coca-Cola, red juices, coffee and tea in this experiment did not show any significant difference. However, most of the studies assume these drinks as the main factors in tooth discoloration development ${ }^{26,23}$. Other similar investigations pointed out that highly pigmented, acidic beverages not only caused tooth discoloration but also dissolution of the ename ${ }^{27-30}$. Joiner et al. also showed that black tea and red wine components had a profound effect on in vitro pellicle maturation while causing thickened layers of stained material to build up ${ }^{23}$.

Extrinsic tooth staining can be caused by compounds that are incorporated into the pellicle and produce a stain consequently to their basic color (chromogen), or those that lead to staining caused by chemical interaction at the tooth surface, which is usually associated with cationic antiseptics and metal salts. Literature data show that brown and black pigmentation contains undissolved iron, probably iron-sulfide, which is formed by interaction of hydrogen-sulfide produced by bacteria from periodontal tissue and iron from saliva or gingival exudates ${ }^{21}$. Nordbo et al. ${ }^{22}$ report on a higher concentration of salivary lactoferrin (ironbinding glycoprotein) in the saliva of a patient with dark pigmented discolorations. Reid et al. ${ }^{21}$ report on traces of calcium and phosphorus in black extrinsic staining. Parnas et al. ${ }^{31}$ also found calcium and phosphorus levels in black extrinsic metal stains, while confirming the opposite by detecting no metallic ions in the samples collected with a graphite curette but only in samples collected with a metal curette. According to these authors, metallic ions do not seem to be the origin of black extrinsic dental stain and previous reports 
on the presence of metallic ions are probably due to contamination of the samples by the collection method, so they did not find any differences between the chemical composition of normal plaque and black extrinsic dental stains ${ }^{31}$. In our study, discoloration samples had traces of calcium, magnesium, iron, copper and zinc.

Tobacco smoking and chewing are known to cause staining $^{32}$. In our study, older patients that were smoking had more discoloration, as also confirmed in other studies $^{32-35}$. There was no difference in drug intake (iron, antacids, and vitamins) between patients with and without pigmentation, which was not in accordance with the study by Pani et al. ${ }^{36}$, reporting that extrinsic tooth staining is caused by iron releasing syrups. Other iron supplements can also cause black pigmentations ${ }^{37-39}$. So, commonly caused drug-induced tooth discoloration can be prevented by avoiding prescriptions of well-known offender drugs known to cause tooth discoloration during pregnancy and in children.

More than $50 \%$ of oral bacteria are non-culturable. Li et al..$^{40}$ used sequencing of the bacterial $16 \mathrm{~S}$ rRNA gene to evaluate oral microbiota in children with and without black stain and found that Actinomyces, Cardiobacterium, Haemophilus, Corynebacterium, Tannerella and Treponema were more abundant in plaque samples of children with black stain, while Saba et al. ${ }^{41}$ used polymerase chain reaction to reveal a significantly higher prevalence of Actinomyces and Aggregatibacter actinomycetemcomitans in black stain compared to the plaque of the control group. Porphyromonas gingivalis and Prevotella melaninogenica were absent from the samples of both black stain and control subjects. It is well known that some Actinomyces strains produce hydrogen sulfide, which can result in ferric sulfide formation in the presence of iron in saliva or gingival exudates ${ }^{42}$. In our study, CRT buffer test was used for buffer capacity of saliva, while CRT Bacteria test was used to determine the presence of $S$. mutans and Lactobacillus spp. Although both bacterial species were found in all groups, patients with pigmentation had less $S . m u-$ tans and lower saliva $\mathrm{pH}$ than patients without pigmentation. Our results differed from the study by Heinrich-Weltzien et al..$^{32}$, who found that $S$. mutans and $S$. sobrinus were not significantly different between the samples of black stains and non-discolored plaque in both caries-free and affected children, while the counts of Lactobacillus spp. were higher in non-discolored plaque samples. Also, plaque samples of black stain had higher numbers of Actinomyces naeslundii and lower numbers of Fusobacterium nucleatum. Garan et $a l .{ }^{43}$ found that salivary $\mathrm{pH}$ was not significantly different between the groups with and without black stains. Costa et al..$^{44}$ and $\mathrm{Li}$ et al. ${ }^{40}$ report on a similar prevalence of $S$. mutans in dental biofilms of patients with and without black stain. The presence of black stain has been reported to be associated with a low frequency of caries, but the reasons are still unknown ${ }^{23}$. Finally, all the above studies indicate a unique microbiological composition of dental plaque with black stain; however, with only a few selected species evaluated, the relationship between microorganisms and black stain still remains uncertain and incomplete. The similar bacterial composition of dental biofilms of black tooth stains and healthy tooth surfaces indicates that black tooth stains are not free of cariogenic bacteria.

This study had some limitations. In clinical conditions, tooth surface is protected by the saliva and enamel pellicle, which is important for tooth discoloration. Variation in salivary composition throughout the day was not analyzed. Also, there is great individual variation in the degree of staining from person to person, which makes the explanation more difficult, as it may be caused by intrinsic factors, differences in extrinsic factors, or both. Black tooth stain is a characteristic extrinsic discoloration commonly seen on the cervical enamel following the contour of the gingiva, and the food or drink intake is related to its formation, so this kind of information is of great importance to both doctors of dental medicine and patients. Prevention of tooth staining and knowledge in the field of tooth discoloration development is very important, especially when recommending oral care products known to cause staining.

\section{Conclusion}

Under the limitations of this study, it is concluded that tooth discoloration is influenced by many factors among which diet is one of the most important ones. Our study showed that patients with black pigmentation used to take more beets, whereas patients without pigmentation used more collard greens and red wine. The problem for a practitioner in everyday clinical 
practice is to find an appropriate method to reduce or stop the formation of pigmented tooth discolorations, so patients taking large amounts of vegetables causing black pigmentation should be warned. Further studies with different population and other food and drink intake are required.

\section{Acknowledgments}

The study was supported by grant No.065-352851410, Ministry of Science, Education and Sports, Republic of Croatia.

\section{References}

1. Harald M, Eriksen HM, Nordbo H. Extrinsic discoloration of teeth. J Clin Periodontol. 1978;5(4):229-36.

2. Šutalo J. Patologija i terapija tvrdih zubnih tkiva. $1^{\text {st }}$ edn. Zagreb: Naklada Zadro; 1994. (in Croatian)

3. Hattab FN, Qudeimat MA, al-Rimawi HS. Extrinsic tooth discoloration. J Esthet Dent. 1999;11(6):291-310.

4. Theilade J, Slots J, Fejerskov O. The ultra structure of black stain on human primary teeth. Scan J Dent Res. 1973;81(7): 528-32.

5. Tantbirojn D, Ko C-C, Douglas W H. Stain removal efficacy: an in vitro evaluation using quantitative image analysis. Quintessence Int. 1998;29(1):28-37.

6. Tantbirojn D, Douglas W H, Ko C-C, et al. Spatial chemical analysis of dental stain using wavelength dispersive spectrometry. Eur J Oral Sci. 1998;106(5):971-6.

7. Bandon D, Chabane-Lemboub A, Le Gall M. Exogenous black dental colorings at the child: black-stains. Arch Pediatr. 2011;18:1343-7.

8. Garcia Martin JM, Gonzalez Garcia M, Seoane Leston J, et al. Prevalence of black stain and associated risk factors in preschool Spanish children. Pediatr Int. 2013;55(3):355-9, http:// dx.doi.org/10.1111/ped.12066

9. Soukos NS, Som S, Abernethy AD, et al. Phototargeting oral black-pigmented bacteria. Antimicrob Agents Chemother. 2005;49(4):1391-6, http://dx.doi.org/10.1128/AAC.49.4.1391 $-1396.2005$

10. Nathoo SA. The chemistry and mechanisms of extrinsic and intrinsic discoloration. J Am Dent Assoc. 1997;128 Suppl: 6S-10S.

11. Cowan MM, Taylor KG, Doyle RJ. Energetics of the initial phase of adhesion of Streptococcus sanguis to hydroxylapatite. J Bacteriol. 1987;169(7):2995-3000.

12. Vogel R I. Intrinsic and extrinsic discoloration of the dentition. J Oral Med. 1975;30(4):99-104.

13. Addy M, Moran J, Griffiths AA, et al. Extrinsic tooth discoloration by metals and chlorhexidine. Br Dent J. 1985;159(9): 281-5.
14. Eriksen H M, Nordbo H, Kantanen H, et al. Chemical plaque control and extrinsic tooth discoloration J Clin Periodontol. 1985;12(5):345-50.

15. Watts A, Addy M. Tooth discolouration and staining: a review of the literature. Br Dent J. 2001;190(6):309-16, http://dx.doi. org/10.1038/sj.bdj.4800959a

16. Lorenz K, Noack B, Herrmann N, et al. Tooth staining potential of experimental amine fluoride/stannous fluoride mouth rinse formulations - a randomized crossover forced staining study. Clin Oral Investig. 2015;19(5):1039-45, http://dx.doi. org/10.1007/s00784-014-1328-9

17. Chhabra N, Singbal KP.Viable approach to manage superficial enamel discoloration. Contemp Clin Dent. 2010;1(4):284-7, http://dx.doi.org/10.4103/0976-237X.76404

18. Sheoran N, Garg S, Damle SG, Dhindsa A, et al. Esthetic management of developmental enamel opacities in young permanent maxillary incisors with two microabrasion techniques - a split mouth study. J Esthet Restor Dent. 2014;26(5):345-52, http://dx.doi.org/10.1111/jerd.12096

19. Sundfeld RH, Rahal V, Croll TP, et al. Enamel microabrasion followed by dental bleaching for patients after orthodontic treatment - case reports. J Esthet Restor Dent. 2007;19(2): 71-7, http://dx.doi.org/10.1111/j.1708-8240.2007.00069.x

20. Nordbo H. Discoloration of dental pellicle by tannic acid. Acta Odontol Scand. 1977;35(6):305-10.

21. Reid JS, Beeley A, Macdonald DG. Investigations into black extrinsic tooth stain. J Dent Res. 1977;56(8):895-9.

22. Nordbo H, Kolsto AB, Eriksen HM. Salivary lactoferrin in a selected group of subjects with exceptional extrinsic dental staining. J Oral Pathol. 1987;16(8):392-4.

23. Joiner A, Muller D, Elofsson UM, et al. Adsorption from black tea and red wine onto in vitro salivary pellicles studied by ellipsometry. Eur J Oral Sci. 2003;111(5):417-22.

24. Proctor GB, Pramanik R, Carpenter GH, et al. Salivary proteins interact with dietary constituents to modulate tooth staining. J Dent Res. 2005;84(1):73-8, http://dx.doi.org/ 10.1177/154405910508400113

25. Chen X, Zhan JY, Lu HX, et al. Factors associated with black tooth stain in Chinese preschool children. Clin Oral Investig. 2014;18(9):2059-66, http://dx.doi.org/10.1007/s00784-013$1184-\mathrm{z}$

26. Pearson D. The chemical analysis of foods. $7^{\text {th }}$ edn. London: Churchill Livingstone; 1976.

27. Ren Y, Amin A, Malmstrom H. Effects of tooth whitening and orange juice on surface properties of dental enamel. J Dent. 2009;37(6):424-31.

28. Prati C, Montebugnoli L, Suppa P, et al. Permeability and morphology of dentin after erosion induced by acidic drinks. J Periodontol. 2003;74(4):428-36, http://dx.doi.org/10.1902/ jop.2003.74.4.428

29. Owens BM, Kitchens M. The erosive potential of soft drinks on enamel surface substrate: an in vitro scanning electron mi- 
croscopy investigation. J Contemp Dent Pract. 2007;8(7): 11-20.

30. Reis C, De-Deus G, Leal F, et al. Strong effect on dentin after the use of high concentrations of citric acid: an assessment with co-site optical microscopy and ESEM. Dent Mater. 2008; 24(12):1608-15, http://dx.doi.org/0.1016/j.dental.2008.03.027

31. Parnas L, Chevion M, Berenshtein E, et al. Are there metallic traces in black extrinsic dental stain? Quintessence Int. 2013;44(5):427-32, http://dx.doi.org/10.3290/j.qi.a29149

32. Heinrich-Weltzien R, Bartsch B, Eick S. Dental caries and microbiota in children with black stain and non-discoloured dental plaque. Caries Res. 2014;48(2):118-25, http://dx.doi. org/10.1159/000353469

33. Whelton H, Kingston R, O'Mullane D, et al. Randomized controlled trial to evaluate tooth stain reduction with nicotine replacement gum during a smoking cessation program. BMC Oral Health. 2012;13:12-3, http://dx.doi.org/0.1186/14726831-12-13

34. Bazzi JZ, Bindo MJ, Rached RN, et al. The effect of at-home bleaching and toothbrushing on removal of coffee and cigarette smoke stains and color stability of enamel. J Am Dent Assoc. 2012;143(5):e1-7.

35. Xie P, Lu J, Wan H, Hao Y. Effect of toothpaste containing dlimonene on natural extrinsic smoking stain: a 4-week clinical trial. Am J Dent. 2010;23(4):196-200.

36. Pani SC, Alenazi FM, Alotain AM, et al. Extrinsic tooth staining potential of high dose and sustained release iron syrups on primary teeth. BMC Oral Health. 2015;15:90, http://dx.doi. org/0.1186/s12903-015-0072-0

37. Zanjani VA, Ghasemi A, Torabzadeh H, et al. Bleaching effect of ozone on pigmented teeth. Dent Res J (Isfahan). 2015; 12(1):20-4.

38. Kumar A, Kumar V, Singh J, et al. Drug-induced discoloration of teeth: an updated review. Clin Pediatr (Phila). 2012; 51(2):181-5, http://dx.doi.org/10.1177/0009922811421000

39. Sales-Peres SH, Pessan JP, Buzalaf MA. Effect of an iron mouth rinse on enamel and dentin erosion subjected or not to abrasion: an in situlex vivo study. Arch Oral Biol. 2007;52(2): 128-32, http://dx.doi.org/10.1016/j.archoralbio.2006.08.010

40. Li Y, Zhang Q, Zhang F, et al. Analysis of the microbiota of black stain in the primary fentition. PLoS One. 2015;10(9): e0137030, http://dx.doi.org/10.1371/journal.pone.0137030

41. Saba C, Solidani M, Berlutti F, et al. Black stains in the mixed dentition: a PCR microbiological study of the etiopathogenic bacteria. J Clin Pediatr Dent. 2006;30(3):219-24.

42. Tek M, Metin M, Sener I, et al. The predominant bacteria isolated from radicular cysts. Head Face Med. 2013;9:25, http:// dx.doi.org/10.1186/1746-160X-9-25

43. Garan A, Akyüz S, Oztürk LK, et al. Salivary parameters and caries indices in children with black tooth stains. J Clin Pediatr Dent. 2012;36(3):285-8.

44. Costa MT, Dorta ML, Ribeiro-Dias F, et al. Biofilms of black tooth stains: PCR analysis reveals presence of Streptococcus mutans. Braz Dent J. 2012;23(5):555-8.

Sažetak

\title{
RIZIČNI ČIMBENICI POVEZANI S NASTANKOM CRNIH OBOJENJA NA ZUBIMA
}

\author{
K. Prskalo, E. Klarić Sever, I. Alerić, T. Antonić Jelić i I. Žaja
}

Svrha ovoga istraživanja bila je dokazati postoji li utjecaj konzumacije hrane, pića ili lijekova na nastanak i pojavnost crnih obojenja na zubima. Ukupno 500 pacijenata u dobi od 15-25 godina pregledano je i uključeno u ovu studiju. Od ukupnog broja, 60 pacijenata je odabrano i podijeljeno u dvije skupine od 30 pacijenata. Skupina 1. je uključivala pacijente s crnim obojenjima na vestibularnim/oralnim plohama zuba. Skupina 2. je uključivala pacijente bez crnih obojenja (kontrola). Podaci su prikupljeni korištenjem posebno pripremljenog upitnika. Atomska apsorpcijska spektroskopija je primijenjena za određivanje elemenata koji uzrokuju i nalaze se u sastavu crnih obojenja zubi. Test rizika karijesa (CRT) korišten je za određivanje puferskog kapaciteta sline, dok je CRT test bakterija korišten za određivanje prisutnosti bakterija Streptococcus mutans i Lactobacillus spp. u slini. Statistički značajna razlika između skupina utvrđena je za kelj i ciklu ( $\mathrm{p}<0,05)$, no ne i za ostalo povrće. Što se tiče konzumacije pića, pacijenti s crnim obojenjima na zubima su pili manje vina $(p<0,05)$ u odnosu na pacijente bez obojenja. Nije zabilježena razlika u konzumaciji lijekova između pacijenata s crnim obojenjima i bez njih. Pacijenti s obojenjima su bili stariji, pušili su i imali su niži $\mathrm{pH}$ sline te nižu razinu bakterije Streptococcus mutans nego oni bez obojenja $(\mathrm{p}<0,05)$. U diskoloriranim uzorcima pronađeni su tragovi kalcija, magnezija, željeza, bakra i cinka. Na nastanak obojenja zuba utječe niz čimbenika, među kojima se prehrana i slina smatraju jednim od važnijih. Ovo istraživanje je pokazalo da pacijenti s crnim obojenjima na zubima konzumiraju više cikle, dok pacijenti bez obojenja konzumiraju više kelja i crnog vina.

Ključne riječi: Zubi; Crna obojenja; Prehrana; Slina 